Александар М. Милановић

Универзитет у Београду

Филолошки факултет

Катедра за српски језик

са јужнословенским језицима https://doi.org/10.18485/ai_zsjoski.2018.1.5 821.163.41.09 Андрић И. 811.163.41'367.623

\title{
АНДРИЋ И БЕОГРАДСКИ ЖИВИ ГОВОР
}

У реферату се анализира Андрићев однос према живом говору, почевши од пишчевог есејистичког сагледавања Вуковог реформаторског дела па до сакупљања говорне лексике коју је исписао у рукописном речнику разговорне београдске лексике. Детаљно су тумачена значења и функције ове лексике у Андрићевом књижевном стваралаштву, посебно у причама са београдском ратном тематиком. Андрић је у приповеткама, активирао многе лексеме из речника у дискурсу јунака и ликова и тексту наратора, али и друге колоквијализме који нису потврђени у речнику. На основу обиља грађе у речнику износи се претпоставка да је Андрић намеравао да напише већу прозну целину, роман са ратним Београдом као главним јунаком.

Кључне речи: српски стандардни језик, језик књижевног дела, колоквијални језик, живи говор, колоквијализам, вулгаризам, фразеологизам.

\section{1. Оквир истраживања: Андрић и стандардни} језик. Језик Андрићевих књижевних дела неретко је узиман као пример узорног стандардног језика. Већ прве студије о Андрићевој прози истицале су језичку хармо-

* aleksandar.jus@gmail.com 
нију у његовој прози. ${ }^{1}$ Петар Џаџић (1957: 214-217), на трагу запажања Исидоре Секулић, међу првима је истакао суштинску Андрићеву улогу у развоју и осавремењивању вуковскога језика будући да му је дескрипција уврежена „у говорни језик и народна предања”. И Драгиша Живковић (1994: 282) издвојио је Андрићев језик као „најскладнији и најхармоничнији српски језик у нашем досадашњем прозном стварању", додајући да је такав језички израз на трагу Вука и Даничића. И Живојин Станојчић (1967: 308) је тврдио да је „Андрићев језик много богатији од Вуковог језика, иако ни по чему не одступа од Вуковог језика као основе на којој достиже и највиши степен развијености". Милош Ковачевић (2013: 34) већ je, сада на трагу истраживања Драгише Живковића и Живојина Станојчића, у својим радовима доказивао како се теорија онеобичајења не може доказати на Андрићевом језику, те да је његов текст идеална грађа за заступнике белићевске нормативне стилистике и нормативног критеријума „језика добрих писаца”, која добар стил књижевног дела препознаје само у оквирима стандардног (књижевног) језика, а све то водило га је кроз стилистичку анализу пишчевог текста закључку да Андрићев језик и стил предстаљају „врхунац Вуковог стила и језика”. И заиста, уколико прихватимо поставку да је књижевноуметнички стил један од функционалних стилова, селектовани примери из Андрићевих дела били би репрезентативни примери српског стандардног језика у књижевности, и ту нема ничега спорног. Међутим, остаје отворено питање да ли је баш сваки сегмент Андрићевог језика истовремено и део стандарднога језика. Да ли је, наиме, Андрић понегде и

1 Појам језичке хармоније произишао је из изјаве Станислава Винавера током дискусије у Пен-клубу 1938. године: „Код њега је потпуна хармонија између онога што је хтео, видео и рекао и чак оног што поједине личности кажу, или не кажу, у складу је са доживљеним током његове приповетке" (Џаџић 1957: 213). 
свесно правио отклон од стандарднојезичке норме, макар на лексичком плану?

У потрази за одговором на ово питање, обратићемо пажњу на Андрићев однос према живом говору. На основу Андрићеве критике књишког славеносрпског језика и похвале вуковском језику видљиво је пишчево начелно залагање за живу народну реч као основу српске националне културе, чак и науштрб традиције: „Као што се у његовој Србији народ дигао просто 'да бије Турке', да би освојио власт у рођеној земљи, тако је и он кренуо да разгони славено-сербске списатеље и да прибави власт народном језику као једином могућем основу истинске и савремене националне културе” (Андрић 1972: 18-19). Повезујући живи народни говор са стварношћу, Андрић је суштину славеносрпске књижевности описао као мутну и магловиту: „У то време су други српски књижевници бродили мутним водама и магловитим крајевима, пишући дела по садржини својој исто тако далека свакој стварности као што им је језик далек језику народа" (Андрић 1972: 36). ${ }^{2}$ Потрага за стварношћу, дакле, писца води ка живој речи, ка актуелном, савременом језику.

Већ је речено како је Андрић активирао босанске дијалектизме „у говору својих личности из Босне, па и то у мери која тај говор приближава општем књижевном језику” (Живковић 1994: 295).

2. Белић о Андрићу као представнику тзв. „београдског стила”. Александар Белић је у свим својим радовима посвећеним модернизацији стандарднога језика с краја 19. и почетка 20. века Андрића сврстао међу главне представнике тзв. „београдског стила”. Истицао је истовремено, што је нарочито значајно, да стандардни тј. „књижевни” језик постаје живи говорни језик, односно „матерњи” језик образованих Београђана:

2 Метафору о томе како се језик мути и бистри Андрић је понављао и у другим есејима о Вуку Караџићу. 
„И београдско грађанско друштво говори књижевним језиком као својим матерњим језиком; зато и оно учествује у стварању живе, увек покретне, увек неуморне у тражењу нових путева и нових излаза - језичке материје. Војислав Илић, Љубомир Недић, Богдан Поповић, Слободан Јовановић, Милан Ракић, Јован Скерлић и др., да поменем, само неколико имена, иако су Београђани по пореклу, ни по чему нису показали да им је недостајала творачка снага у језику. Већ - напротив!" (Белић 1940а: 194).

И писци који су стизали у Београд из других крајева, наглашава даље Белић, брзо су се укључивали у процесе модернизације стандарднога језика у престоници, „добијајући од Београда општи колорит”. Од ових писаца Белић је овом приликом издвојио само четири имена, међу којима је и Андрићево:

„С друге стране, сви књижевници који са стране долазе, из ближих и даљих крајева, од Љубомира Ненадовића до Симе Матавуља, Јована Дучића, Ива Андрића и других, добијајући од Београда општи колорит, брзо постају учесници, каткада снажни, други пут врло танани и гипки, у изграђивању истога ткива књижевнога језика. Чињеница, што се то врши са великом лакоћом, без икаквих трзавица, - и показује како је код њих и код београдских књижевника била иста народна основица књижевног језика. Она и јесте главни покретач творачких могућности код њих" (Белић 1940а: 194).

Белићева формулација о добијању „општег колорита" сведочи о језичким утицајима које је културни центар вршио на писце који су стизали са периферије, односно о жељи писаца да се уклопе у комуникацијске токове града који је нагло растао, архитектонски и културно. Стварали су се тако истовремено и модернизовани и интелектуализовани стандардни језик и разговорни језик образованих кругова: 
„Само не треба мислити да се ничим не разликује књижевни језик Београда од разговорног или уличног језика тога града. Као увек када књижевни језик преовлада у каквом средишту, тако се и у Београду напоредо са књижевним језиком ствара и разговорни језик образованих кругова. Он стоји према књижевном језику исто онако као што на пр. језик Мостара стоји према језику Алексе Шантића, или језик Змијања или Бања Луке према језику Петра Кочића" (Белић 1940а: 194).

Андрић се од 1919. године нашао у средишту значајних иновацијских процеса у српском језику и активно је у њима учествовао. Живи говор Београда, и то не само његових „образованих кругова”, снажно га је привлачио, и у њему је проналазио грађу за дела посвећена стварности престонице.

3. Андрић лексикограф. За разумевање пишчевог односа према београдском живом говору као извору за језик књижевности веома је значајан мало познати детаљ о Андрићу као лексикографу. Наиме, у заоставштини је остао Андрићев рукописни речник исписиван у једној свесци са тврдим корицама, намењеној азбучној нотацији података. Име Речник одомаћених речи и израза (у даљем тексту: Речник) дато је при каталогизовању личног фонда Иве Андрића, није Андрићево. Из кратког оквирног текста Даринке Гортан-Премк (1996: 9) о Речнику сазнајемо: „У самој свесци нема назива речника, а како је до њега дошло још увек не знамо; знамо само то да назив одговара садржају. Речи је записивао у различито време, кад би их у каквом разговору чуо или, ређе, када би их негде прочитао; ове из писаних текстова ексцерпиране речи Андрић је накнадно сам прецртао. Тако је добијена лексичка номенклатура грубо уазбучена само према иницијалним графемама, али не и у оквиру иницијалне графеме."

У овом информативном тексту Даринка Гортан-Премк није постављала стилистичка и поетичка питања, међу 
којима је кључно: Зашто је Андрић бележио разговорну лексику у Речнику? Она, додуше, на основу прецртаних речи у Речнику (архаизама, локализама и туђица) износи занимљиву претпоставку која не задире у домен узрока писања Речника: „Ово нас, даље, упућује још на једну претпоставку, на претпоставку да је Андрић одустао не само од навођења извора већ и од почетне концепције речника; рекло би се да је први циљ био речник необичних, неодомаћених речи, а каснији и остварени - речник обичних, одомаћених речи" (Гортан-Премк 1996: 42). Рајна Драгићевић (2018: 190), опет, износи претпоставку да је Андрић речи „вероватно бележио с намером да оживи дијалоге у својим делима”.

Исписивањем своје свеске и Андрић је стао у ред вуковаца што су на трагу Вуковог Српског рјечника (1818, 1852) постали и лексикографи, а међу часним именима посебно треба издвојити Лазу Костића, који је такође сакупљао народну лексику незабележену код Вука. ${ }^{3}$ Лексика у Андрићевом Речнику махом је са београдских улица, пијаца и из београдских ресторана, кафана, кућа и станова, мада не сва, на шта указују Андрићеве локализације у објашњењима: бабар зову у J. Србији, у рудницима радника кога издржава жена (14), ја̀јара (сељак, нерадник и крадливаи, из околине Београда) (21); "Крш, у Црној Гори „и драго камене не зову друкчије него „кри”. (21), труцирати (из Прека) (35), утман у J. Срб. рудар (Hӥttemann), али у исто време и синоним за скитнииу и бескућнике (35), укметити се, чуо сам од једне Босанке [?] y Београду = засести и не хтети устати с места (35), „хардауш” - неред, кри (по кући), из Зворника (38).

3 Линију писаца-лексикографа наставили су на специфичан начин, романима-речницима, Милорад Павић и Миро Вуксановић, као и књижевници којима је лексикографија и израда РСАНУ професија - Милосав Тешић и Васа Павковић.

4 Временом је ова лексема проширила значење у београдском жаргону. 
Очекивана је претпоставка да је Андрић свакодневну лексику бележио као потенцијалну грађу за своју прозу, пре свега за актуелизацију говора књижевних јунака и ликова, али и приповедача. Уколико наведене ређе „небеоградске" примере оставимо по страни, логично је да београдску колоквијалну лексику ваља пре свега потражити у циклусу од осам приповедака тј. прича са београдском тематиком, у којем су оне повезане скорашњим историјским периодом (Други светски рат) и типизацијом личности о којима се приповеда. ${ }^{5}$

4. Актуелизација београдског живог говора. Иако је Петар Џаџић (1957: 182) констатовао како је Андрић „подбацио у слици велеградског живота” у београдским причама, то се не може рећи и за језичку слику града у њима. Ако пођемо од става Д. Живковића (1994: 295) да код Андрића „идиоматичних израза има у говору личности $[. .$.$] , па и то ретко, а у говору приповедача ретко кад”,$ онда морамо приметити да су београдске приче, у којима се писац не враћа у прошлост већ описује актуелна збивања, унеле значајну стилистичку новину у његову прозу, будући да се говор јунака снажније актуелизује, а кроз поступак цитатности делимично и нараторов текст.

Андрић као мајстор поступка сказа у дужој и познатијој приповеци „Зеко” пажљиво актуелизује исказе капетана Мике, једног од јунака, у обраћању Зеки: „Nemoj ti, brate, kao tamo taj 'svaki od vas', i ostavi ti njih nek idu kud su pošli, nego nabavi nešto pruta s nekoliko udica, skini tu kragnu i te andrmolje sa sebe, pa sedi ovde pored mene - upravo, nemoj pored mene, nego malo podalje, jer ćeš mi rasterati ribu kao svaki bilmez" (Андрић 2016: 46). Стилски маркирана лексема андрмоље из цитата налази

5 Ове приповетке тематски су први пут груписане у издању које је припремила Задужбина Иве Андрића, а објавила Лагуна 2016. године под насловом Beogradske priče. Примери у раду биће навођени према овоме издању. 
се и у Андрићевом Речнику: андрмо́ље (дроњици) (13). ${ }^{6}$ Веома је занимљиво да је ова реч наведена и у Речнику српскохрватскога книжевног језика, ${ }^{7}$ али само са потврдом из - ове Андрићеве приповетке, што значи да је Андрић снагом свога књижевног ауторитета колоквијализму обезбедио статус стандардне, нормиране лексеме. ${ }^{8}$ У истој приповеци јунакиња Маргита изговара реченицу која звучи сасвим живо, аутентично: „То im je uneo u kuću Dorošev sinovac, onaj žgoljavi Siniša, a ona špica, Jelica, zaludela i braću i majku" (Андрић 1996: 77). И маркирана лексема шпица потврђена је у Речнику: шпица (препреден човек или жена) (41).

Са друге стране, и Андрићев свезнајући приповедач, наратор, свој текст актуелизује речима локалне београдске средине, додатно наглашеним и издвојеним од остатка текста наводницима као маркерима цитатноcmu: „Tako je porastao do fudbalera, pa do prvaka u tenisu i do savršenog tipa savremenog beogradskog 'lafa"' (Андрић 2016: 41). И жаргонизам лаф потврђен је у Речнику: лаф (-чина), лафица (24).

Ако је, дакле, веома лако доказати да је Андрић део лексике из Речника већ активирао у својој прози, ваљало би дубље проанализирати састав речника као путоказ ка темама о којима је писац писао или планирао да пише. С обзиром на Андрићеву биографију, његову дипломатску каријеру и сналажење у измењеним околностима после револуције, нарочиту пажњу из тог угла може привући лексика која се односила на актуелни политички живот. Већ је Даринка Гортан-Премк (1996: 50-51) уочила „ново

6 У РСАНУ: „андрамо́ље ж мн. [...] ствари без вредности, прне, дроґии, дрангулије; андрмо́ља ж в. андрмоте (Бос. Петровац, Зор. Д.)”.

7 У РМС: „андрамо́ље ж мн. грч. стареж, тралье, дроњии, непотребне ствари."

8 У једнотомном Речнику српскога језика (РСЈ) из 2011. ове лексеме, опет, нема. 
значење лексеме клуподер, коју је Андрић идентификовао само колокативним лексичким партнером политички; претпостављамо да се ово значење развило после Другог светског рата, у време фронтовских састанака и политичких кружока. Овоме времену могле би припадати, ако не настанком, оно фреквентном употребом, и лексеме типа напаковали су му, висе му ноге, надртао је, слугераға (са дефиницијом у полит. полемици) и сл. А времену пре Другог светског рата, свакако, припада значење лексеме скакаваи, (човек који прелази из једног места у друго и тако добива класе)." Овоме списку колоквијалних политичко-идеолошких израза, који су представљали имплицитну критику постојећег друштвеног система, можемо додати још: возати кога (заваравати, намерно отезати решене једне ствари) (15); гур-гур (човек који се гура на прва места и отима за положаје) (16), дрмаџија, дрматор (17), лакташ (в. гур-гур) (24), пелцован (за човека који доставльа полицији а није прави агент) (31), сецовати (у картама) „На рђаву је карту сецовао” ( $у$ политици) (32). Андрић је, очито, пажљиво прикупљао народне реакције на актуелну политичку и идеолошку стварност, прикупљајући најекспресивније језичке одразе акумулираног незадовољства.

5. Андрићева социолингвистичка запажања. У Речнику се Андрић представио и као добар социолингвиста који прецизно запажа лексичке разлике у различитим жаргонима и специфичним типовима дискурса. Тако је из „дечјег језика” тј. „дечијег аргоа” писац унео следеће примере: ке́ва (мајка у дечјем језику) (22), клинац = дечак (y дечјем говору) (22), калпиш ударити (код дечијег санкана, кад једне санке ударе друге позади) (22), мутерка (дечији арго) (25), пикавац (за малог дечака) (29), ћале (отаи, у дечјем говору) (35), фатер (у дечјем говору) (37), цо̀кити (пољубити, код деце) (39), швестерка (дечији арго) (40). ${ }^{9}$

9 Уп. Драгићевић 2018: 191-192. 
Из омладинског дискурса и жаргона пренети су изрази дати у комуникативном контексту: „Врло важно!” одговор младог света на сва питань. (15); врисак! („Јао, што је врисак” каже се кад је неки човек или ствар смешна (15). ${ }^{10}$

Изврсно језичко осећање Андрић је демонстрирао и бележећи карактеристичне детаље кафанског дискурса: „вади флеке” каже се за шприцер после пијанке (15), Обори! (виче се у пијании, обично: „Обори, Ленка!”) (27). Посебну пажњу Андрић је посветио још и картарошком дикурсу, што такође сведочи о пишчевој склоности ка изучавању језика градске маргине као средине тематски погодне за књижевно стваралаштво: густирати (карту у игри, јело) (16), „наћи кога у педесет и две” („куд га нађе у педесет u две” т.j. карте) (26), пиксла (код картань) (30), паковати (-ње) (у картама) (30), сецовати (у картама) „На рђаву је карту сецовао" (у политици) (32), уплаткати се = пропасти, изгубити, од игре карата (платка) (36). Са друге стране, у Речнику скоро уопште нема спортске жаргонске терминологије и израза иако знамо да је био велики Звездаш и да је радо одлазио на утакмице, нарочито кошаркашке. Једини забележени пример из навијачког диксурса гласи: Тај је бог за фусбал. Бог, богова, нема шта!" (14). Очито је спорт Андрићу био близак као разбибрига, али га је сматрао књижевно незанимљивом темом.

Тачно је и запажање „да се према семантичким пољима која ове лексичке јединице покривају не може ништа закључити о професији говорника; ова су семантичка поља везана за градско живљење и за градску доколицу" (Гортан-Премк 1996: 50).

6. Жена у Андрићевом Речнику. Уколико пажљиво прочитамо приповетке „Породична слика”, „Зеко” и

10 Лексему врисак касније су у београдском омладинском жаргону замениле речи пиш, шоу и сл. (Oн је живи пиш; Oн је шоу невиђени и сл.). Данас је као жаргонизам сасвим архаична. 
„Затворена врата” и обратимо пажњу на јунакиње и женске ликове у њима, лако ћемо разумети зашто је у Речнику Андрић углавном похранио лексеме које означавају жене са негативним особинама. Неке од њих остале су незабележене у речницима (нпр. кајафа, капислара и др.). Изненађује број и разноврсност ових лексема: апа-драпа („она је апа-драпа" = неуредна у кући и оделу) (13), авлијара (жена свађалица) (13), акреп (за жену) (14), ајма̀на (за човека и жену) (14), бабац (за стару жену) (14), врдала̀ма, врдакати, врднути (за жену) (!5), „витка ко̂ плајваз” (за жену) (16), Геновева $\oint$ (каже се подругъиво за некужену) (16), гадура (за жену) (17), дропља (за жену) (17), жентурача (18), „из руке једе” (за лаку жену) (20), Измотација (за човека и жену) (20), калаштура (21), камењарка (проститутка) (22), кајафа зла жена (човек?) (23), капислара = старија жена (23), линцура (погрдно за жену, иначе, трава) (24), лорфа (за жену, „дошао са оном својом лорбом”) (24), лепотиња („она неггва ---”) (24), миражџика (26), опајдара (27), оштроконђа (28), поло̀жара (29), профукљача (31), ${ }^{11}$ роспија (31), сринтати се (за дебелужену) (33), „витка коิ плајваз” (за жену) (34), трзати („трза, не трза", кажу мушкарии за жену коју изазивају погледима према томе да ли она одговара или не) (34), трапађо́за (за жену) (34), фаћкати (-лица, жена), филомена (подругт. за жену) (38), џубрѐтара (за жену, у морал. смислу) (39), џафтара (жена на злу гласу) (40), шиндивиља (врикасто женско) (40), шмизла (за девојку „Она юена шмизла”, подругльио) (40). Лексема са позитивним значењем готово и да нема, искључујући једну: лаф (-чина), лафица (24).

7. Мушкарац у Андрићевом Речнику. Мушкарци су у Речнику рељефније представљени, а наведене су њихове различите особине. Неке од њих су описане као емотивно

$11 \mathrm{y}$ савременом београдском разговорном језику забележили смо и форму са /nj/: профукњача. 
неутралне: даса = човек, мушкараи, (щатров.) (17), кусоња (човек у шали) (22), фрајер -и = гледаоии у позоришту са бесплатном улазницом, уопште: младићи, боеми (37), ${ }^{12}$ шило (за немирна човека) (41). Друге су, пак, са негативим конотацијама по различитим параметрима: адраповац (13), глодавац (чиновник који краде) (17), дрипац (-чина), даса (uатр.) (17), дркеља (за стариа) (18), задрибалда (борбен, осион човек) (19), јајара (сельак, нерадник и крадљиваи, из околине Београда) (21), лудија (бесан и луд човек) (24), луцпрда (човек без памети) (24), мангуп (26), мућак (за човека) (26), нокташ (женскар) (26), наивко (27), нервоштина (за човека) (27), пргавштина (за човека пргава) (30), сигурација (ирон.) = несигуран човек (32), тутумрак (бојажтьи, подмукао (34), тарла́ја (брбльивач-ица) (34), ${ }^{13}$ то́пузина (за глупа човека) (35), џимрија (трвдица) (40). Андрићева објашњења уз лексеме воде нас типовима карактера који писца посебно занимају. Тако је за лењог мушкарца, каквих има и међу Андрићевим јунацима („Зеко”) наведено је више маркираних и немаркираних синонима: ладолеж (ленштина) (24), ленчуга (24), муфљуз (бадавачија) (26). Чак две лексеме у Речнику означавају мушкарца економски зависног од супруге: бабар зову y J. Србији, у рудницима радника кога издржава жена (14), мучибабић (човек кога издржава жена старија од юега.) (25).

Андрића посебно привлаче лексеме за именовање вештих и мудрих мушкараца, а нарочито лукавих: па̀љевина = вешт, лукав и окретан човек (29), ${ }_{14}^{14}$ видра-човек = лукав, окретан (16), кефало (мудар и лукав човек) („А, кебало је mo!") (22), префакута = лукав човек (31). Ту су и лексеме за именовање препредених и превејаних: шпица (препре-

12 Лексема øрајер данас, не само у београдском жаргону, има другачије значење.

13 Забележено у београдском жаргону, чак и у надимку (уп. Бата Трлаја), и у форми: трлаја

14 Лексема паљевина данас у београдском жаргону има сасвим супротно значење: „наиван човек који брзо поверује и са одушевљењем прихвати”, тј. који се брзо напали на нешто. 
ден човек или жена) (41), штих - превејан човек (41). Ако пажљиво анализирамо главне јунаке и друге мушке ликове Андрићевих београдских приповедака и њихов однос према женама, пре свега својим супругама у причама „Породична слика” и „Зеко”, не треба да чуди ни селекција следећих лексема: аминаш (човек који све повлађује) (13), „здушна баба” (каже се за сувише блага и добра човека) (19), мрљавити (-вко) (26), мутавко (26), папучар (за мужа) (31), туњавко (34). Насупрот њима, налазе се неодољиви освајачи женских срца: локер (леп човек који у мушком друштву привлачи жене) (24), флит, у значену: неодољив човек пред којим све пада (нарочито жене), а долази од енгл. назива једног прашка против инсеката. („A, тај је флит!”) (37). ${ }^{15}$

Чини нам се посебно занимљивим да је у београдским причама Андрић активирао и друге колоквијалне лексеме за означавање особа женског и мушког пола, којих нема у Речнику, а сасвим су налик забележеним. Ту мислимо, на пример, на лексеме мукташ, шона или аспида: „а ima i profesionalnih krijumčara i kockara, pevača, ženskara i muktaša” (50); „on je, hvala bogu, šonja kakav je uvek i bio” (77); „Kad bih znala nigde na svetu službe da nema, ne bih takvu aspidu služila" (103-104). ${ }^{16}$ Лексема женскар из првог примера, опет, није потврђена као одредница већ као синоним при семантичкој идентификацији у Речнику: нокташ (женскар) (26). Очито

15 „У овоме језику, као и у свакоме разговорном језику, има и речи жаргонских, а и скарадних, вулгарних. Готово све оне, и оне разговорне и оне скарадне, у своме семантичком садржају имају и експресивне, конотативне семе, чешће негативне него позитивне, што је и нормално за овај тип лексике” (Гортан-Премк 1996: 49). Слично констатује и Р. Драгићевић: „Међу називима за особе највише је оних који имају непожељно значење. Овај податак је очекиван јер га потврђује већина збирки речи." Ова потпуно тачна запажања ипак, показују примери, мање важи за лексеме које означавају мушкарце но жене.

16 Исто важи и за колоквијализме другачије семантике: у Речнику, нпр., нема ни глагола зарезивати, потврђеног у приповеци „Зеко”: „Ovoga gospodina Zeku ne zarezuje baš niko” (42), и сл. 
је писац бележио само оне речи које су му биле непознате, нове, а довољно експресивне.

8. Конструкције у Андрићевом Речнику. Писцу Андрићу очито није стало да језик својих јунака и ликова актуелизује само свакодневном а живописном лексиком, па у речник уноси и многе фразеологизме, од којих пет нису забележени у речницима. Број и експресивност унетих разговорних фразеологизама заслужују дужу илустрацију: „Бог и батина” (14), бити жицу (бије жииу = nросјачu) (14), „вакелу очитати” коме (15), „весло сисати” („нисмо ни ми весла сисали” = знамо и ми нешто) (15), душу јести коме (задиркивати. „Е, душу смо му појели”.) (17), „дићи руке од кога" (напустити га) (18), извући коме асуру = нашкодити му, упропастити га (20), изводити кривине = намерно замрсити ствар „Шта ми mу изводи кр.?" (20), "удараити јадаи" кликер = преварити кога (20), „ударио му кликер” (22), канта („привезали му канту" = измислили неку клевету) (У палании привежу псу за реп канту) (22), миндроз (узети кога на -) (26), „неће тај на трулу даску” (26), „наћи кога у педесет и две” („кид га нађе у педесет и две” т.j. карте) (26), нумера („скочила му нумера”) („и он је мумера!”) (27), „не дирај у обарачу” (27), обрати бостан = пропасти (27), околност („вата га околност”) (28), „оде воз!” ( = неповратно изгубъено) (28), померити коме даску (цименту) = yпропастити га, нанети му штету (28), „, па ће да игра пипиревку" = да види муку (29), појести коме панаију = саранити га (30), ${ }^{17}$ „Подупирати кућу с крова” = штетити коме (30), реп („иде реп за ғим”) (31), смрсити коме конце = уништити га (32), „спустити дурбин” (32), савити шипке („он сави шипке, па оде”) (32), Тоша („правити се Тоша! тј. луд)" (34), ударити - јадаи, кликер, чар-

17 Д. Гортан-Премк (1996: 30) овде додаје: [треба: сахранити га], али ми сматрамо да је Андрић намерно забележио разговорни фонетски лик глагола. 
ламу, квекер (36), „уватио га у све четири” (36), фрч („ударити коме фрч" = направити му пакост, тешкоћу) (38), фура („извући фуру” = добити грдюу) (38), чапраз-диван (коме чинити) (39). Пажљиви и прецизни аналитичар Д. Гортан-Премк (1996: 42) установила је да Речник садржи „656 лексичких јединица, односно 555 лексема и 101 фразем датих под 586 јединица, лема.”

Нарочиту пажњу привлаче живописна устаљена поређења забележена у Речнику: бос у бару („улетео као бос у бару") (14), вреди му много, као були гаће (ирон) (15), витка ко̂ плајваз” (за жену) (16), „запео ко сивоња” = упоран (19), „као кебу иза појаса” (22), крља (прилепио се као) (23), слистити (брзо појести неко јело) („као Влах numy”) (32), „треснуо га ко̂ жабу о лед” (34), упрскати (ко̂ ћуран мотку”) = не успети, зло проћи (36), „Удесио га као белу лалу" (36), уредити кога као Влах питу или као Панта бабу, каже се кад неко неког упропасти (36).

Осим лексема и фразеологизама, Андрић је забележио и већи број колоквијалних израза: Алал му вера! (13), Врдати, врдање („нема врдана!”) (15), вуна („А, бато, вуна, вуна!” = cmpax) (15), „где би ми био крај” (да сам то и то учинио) (16), „дај шта даш” (17), „Да му је мајка Јана” (17), „другом ти то, бато..." (m.j. причај) (17), „зорт и компанија” (19), Иди ми - дођи ми (20), ја џа̀ - ја бу (илu - или) (21), клај-клај (споро) (21), „миц по миц” = (мало по мало) $(26)$, „на мртво” (удвара јој се на мртво т.j. јако) (26), овам'те, онам'те (ов'те, он'mе, оде хильадарка) (28), „Од блата ћете ме правити” (28), „окрени - обрни” (28), повуци - потегни (28), „плаче казамат за њим” (31), резон (-ски adj.) („нема резона” „поступио је резонски”) (31), трт-мрт („нема ту трm-мрm!”) (33), „Трт Маро, свира банда!” (34), танте за танте! (34), „таман посла” (34), ${ }^{18}$ „тандара-броћ!” (35), „там-те, онам-те” (35), упалити („упалио му кеи" = успело [?] му) (36), „уредио га прописно”

18 Забележили смо у београдском говорном језику и у форми: таман посо. 
(37), „умрем ти на причу” (37), „хоће бити, неће бити” (38), џаба га било! (40), шенити (од пса) = бити слепо покоран „Знаш како шени пред ғом!” „Има тај да ми шени! Знаш како!" (40). Уз поједине од њих стоје и прецизирања везана за комуникативну функцију, значење или фреквенцију у говорним ситуацијама: „без трага му глава!” врло често (15), „има да падне част” (кад неко треба да части) (20), „Има да га нема!” (као претьь) (20), „ради радња” (- се посао, ирон. u cл.) (31). У вези са комуникативном функцијом, посебно привлачи следеће Андрићево објашњење израза који имају функцију поштапалица: „Ето, сад!” не значи ништа а употреблава се врло често, као и „Ене, гле!" (18).

9. Вулгаризми у Андрићевом Речнику. Када узмемо у обзир Андрићев стил, како књижевни тако и животни, помало чуди селекција следећих вулгаризама: ј -- ветар (21), ${ }^{19}$ једнорупић (21), ${ }^{20}$ одрадити (жену) (27), педер (29), сурдукнути (33), хоп-курва (38). Изненађује и појава једног жаргонизма: зезање (-ти) (18). Заиста је тешко предвидети текст и контекст у којима би Андрић књижевно активирао селектоване лексеме. Да ли то сведочи да о Андрићу не знамо довољно?

10. Београдски разговорни фонетски облик лексема. Посебно треба истаћи да је у потрази за што аутентичнијим описом Андрић поједине навео или дефинисао у говорној форми, са карактеристичним фонетским одступањима од стандарда: појести коме панаију = саранити га (30), „уватио га у све четири” (36), чкарт (жкарт) (39), џубрѐтара (за жену, у морал. смислу) (39). ${ }^{21}$

19 Несумњиво се ради о „императивној” сложеници јебиветар, како лексему реконструише и Д. Гортан-Премк (1996: 21, ф. 58).

20 Уп.: „Реч једнорупић није забележена у дескриптивним речницима. У Речнику жаргона она је забележена и дефинисана као онај који полно живи само са једном женом" (Гортан-Премк 1996: 21, ф. 59).

21 Д. Гортан-Премк (1996: 39) додаје: „[треба: ђубрѐтара]”. 
11. Закључак. Андрићу је као књижевнику несумњиво било стало до промена које је у прозни израз уносио тзв. „београдски стил” и делимично је у њима и учествовао на самоме крају епохе, али му је пажњу привлачио и изазовни београдски разговорни и колоквијални израз, и не само београдски. Окретањем ка актуелном живом говору стварао је и следио модерне токове послератне српске књижевности, који су све више своје стилске изворе препознавали у живом говору. ${ }^{22}$ Сведочанство о Андрићевом интересовању за живу београдску реч налазимо у рукописном Речнику одомаћених речи и израза. Само делимично проучен, он оставља иза себе бројна питања без одговора. Једно је како je, с обзиром на повучени начин живота у Београду, далеко од „обичнога света”, сакупљао актуелну разговорну лексику и када ју је бележио. Занимљивије питање, које још једном обнавља дилему о томе колико смо заправо познавали Андрића, јесте зашто је толико прецизно описивао и дефинисао неке лексеме: у многим речничким чланцима налазимо акценат, дефиницију, примере, опис комуникативне ситуације и сл. ${ }^{23}$ Да ли је можда планирао да речник једнога дана допуни, приреди и штампа? Ово питање на значају нарочито добија када погледамо поједине унете вулгаризме, које тешко можемо замислити у Андрићевој прози.

Важно је, такође, истаћи да је Андрић лексику за Речник вероватно сакупљао пре објављивања првих савремених српских речника, Речника САНУ (1959-) и Речника МС (1967-1976), те да они нису могли утицати на Андрићеву селекцију лексике нити на обраду речничких чланака. ${ }^{24}$ Да ли

22 Станислав Винавер у тексту Београдски говорни језик" из 1950. године креће сличним путем, само са другачијих поетичких полазишта (уп. Милановић 2015).

23 Ређе су речи које нису „семантички идентификоване” (ГортанПремк 1996: 44-48).

24 Д. Гортан-Пртемк (1996: 50) сматра „да су ове Андрићеве речи, свакако не све, биле саставни део лексике разговорног језика 
је Речник заправо настајао као лексичка грађа за Андрићеву већу прозну целину, роман са ратним Београдом као главним јунаком, о чему има назнака у инспиративној напомени која прати Beogradske priče, остаје да покажу даље анализе. Материјал који пружају постојеће београдске приче пружа довољно потврда за такву претпоставку, будући да је у њима типизација многих јунака и ликова, али кроз цитате и позиција наратора, извршена кроз актуелизацију колоквијалне и разговорне лексике.

\section{Извори}

Андрић 1972: Иво Андрић о Вуку Каращићу (прир. Ђуро Гавела), Београд: Београдски издавачко-графички завод. Андрић 2016: Ivo Andrić, Beogradske priče, Beograd: Laguna.

\section{Литература}

Белић 1934: Александар Белић, „Београдски стил”, Наш језик, II, св. 7, 193-200.

Белић 1940а: Александар Белић, „Београд и књижевни језик”, Наш језик, VII, св. 7, 193-196.

Белић 1940б: Александар Белић, „Од Вука до Андрића..., Правда, 27-30. IV 1940.

Гортан-Премк 1996: Даринка Гортан-Премк, „Речник одомаћених речи и израза", Посебан отисак из Свезака Задужбине Иве Андрића, бр. 12, 9-51.

Драгићевић 2018: Рајна Драгићевић, Српска лексика у прошлости и данас, Нови Сад: Матица српска.

Живковић 1994: Драгиша Живковић, Европски оквири српске къижевности V, Београд: Просвета.

београдске средине пре 50-60 година". Све приче са београдском тематиком настале су у периоду 1946-1951, непосредно после Другог светског рата, осим приповетке „Разарања”, која је објављена 1960. године. 
Ковачевић 2013: Милош Ковачевић, Српски писии у озрачју стилистике, Београд - Гацко: „Филип Вишњић” - Српско културно и просвјетно друштво Просвјета.

Милановић 2015: Александар Милановић, „Ратни другови у контексту Винаверових погледа на песнички језик”, у: Поезија и модернистичка мисао Станислава Винавера (ур. Предраг Петровић), Београд - Шабац: Институт за књижевност и уметност - Шабачка библиотека, 2015, 235-256.

PMC: Речник српскохрватскога книжевног језика, 1-6, Нови Сад (- Загреб): Матица српска (- Матица хрватска), 1967-1976.

РСАНУ: Речник српскохрватског књижевног и народног језика, 1-19, Београд: Институт за српски (српскохрватски) језик САНУ, 1959-2014.

PCJ: Речник српскога језика, Измењено и поправљено издање, Нови Сад: Матица српска, 2011.

Станојчић 1967: Živojin Stanojčić, Jezik i stil Iva Andrića (funkcije sinonimskih odnosa), Beograd: Filološki fakultet.

Џаџић 1957: Петар Џаџић, Иво Андрић : есеј, Београд: Нолит.

Aleksandar M. Milanović

\section{ANDRIĆ AND BELGRADE SPOKEN LANGUAGE}

This paper focuses on Andrićs attitude towards spoken language, from the way he regarded Vuk Karadžić's language reform in his essays to the Nobel Prize winning author's gathering of lexemes found in the spoken Belgrade vernacular which were collected and recorded in a hand-written dictionary of Belgrade lexis. The dictionary contains colloquialisms, jargonisms, neological formations and vulgarisms of diverse semantics and origin. The meaning and function of such lexemes in Andrić's writings ( especially those set in Belgrade and related to WWII topics) are thoroughly analyzed. Thus, the entire analyzed corpus is classified into the following classes of lexemes: a) those typically used by female or male characters and compared against the characters using them, b) those 
used by children or young adults, 3)those spoken in pubs, during gambling sessions, etc.

In his short stories, through his characters, Andrić utilized not only many lexemes recorded in the dictionary but also colloquialisms whose use and status could not be attested in the dictionary. According to the amount of lexical material found in the dictionary, it is assumed that it was Andrićs intention to write a novel whose main character would have been a war-time Belgrade.

Key words: standard Serbian, the language a literary work, colloquial language, spoken language, colloquialism, vulgarism, phraseologism. 